\title{
O JOGO ENTRE ELITES E INSTITUIÇÕES: as estratégias políticas de ACM Neto e a tradição carlista
}

\author{
Carla Galvão Pereira*
}

\begin{abstract}
Este artigo tem por objetivo principal analisar as estratégias de um ator político no cenário baiano e nacional, ACM Neto (atual prefeito de Salvador), e sua relação com a tradição carlista, grupo formado no Estado da Bahia em torno da forte liderança de seu avô ACM que, durante algumas décadas, foi o político mais importante do Estado e um dos mais influentes do Brasil. Tendo como pano de fundo teórico a relação entre elites e instituições políticas em democracias contemporâneas, o trabalho busca identificar as estratégias deste ator político entre anos de 2002 e 2016 discutindo como ACM Neto se relacionou com o grupo carlista e sua tradição. Para tanto, analisa a atuação parlamentar e alianças políticas construídas no âmbito do seu mandato como deputado federal (2002-2012) e o repertório simbólico mobilizado nas campanhas proporcionais para deputado federal $(2002,2006,2010)$ e majoritárias para Prefeito de Salvador $(2008$, 2012, 2016).
\end{abstract}

Palavras-chave: ACM Neto. Carlismo. Elites Políticas. Instituições.

\section{INTRODUÇÃO}

Este trabalho ${ }^{1}$ analisa as estratégias de um ator político no cenário baiano e nacional, Antônio Carlos Peixoto de Magalhães Neto (ACM Neto), e sua relação com a tradição do grupo que se constituiu, por muitos anos, em elite política dominante no Estado da Bahia, comandada pelo forte poder pessoal de seu avô, Antônio Carlos Magalhães (ACM).

Mais especificamente, o artigo analisa as estratégias políticas de ACM Neto e sua vinculação ou afastamento da tradição carlista a partir de três aspectos: sua atuação parlamentar como deputado federal entre os anos de 2002 e 2010, o repertório simbólico por ele mobilizado nas campanhas para deputado federal (2002, 2006 e 2010) e para prefeito de Salvador (2008, 2012 e 2016), e as alianças políticas construídas ao longo desse período.

\footnotetext{
* Universidade Federal da Bahia. Faculdade de Filosofia e Ciências Humanas. Departamento de Ciência Política.

Rua Aristides Novis, n. 197. Cep. 40.210-909. Federação Salvador - Bahia. galvaocp@yahoo.com.br

${ }^{1}$ Este artigo é parte de uma pesquisa de doutorado intitulada "Renovação como estratégia de preservação: ACM Neto e a tradição carlista” (Pereira, 2014).
}

O artigo versa, portanto, sobre os processos adaptativos de uma elite política longeva num contexto subnacional frente a diversas situações, de modo que a preocupação teórica que fundamenta esse objeto se vincula ao estudo da relação entre elites e instituições políticas nas democracias contemporâneas. Mais especificamente, o estudo analisa o comportamento $^{2}$ de uma elite política frente às instituições e em diferentes contextos políticos. Segundo Peres (2008), uma das preocupações mais clássicas da ciência política reside na reflexão sobre as decisões políticas, se responderiam a algum tipo de restrição exógena à ação configurada pelo arranjo institucional ou a uma racionalidade endógena aos atores e elites políticas. A preocupação com essa última questão fundamentou o surgimento de diversas teorias institucionalistas que buscam explicar o papel desempenhado pelas instituições na determinação de resultados sociais e políticos, e se tornaram uma perspectiva he-

2 Importante é ressaltar que o artigo não pretende dar conta de analisar teoricamente em que medida a atuação dessa elite política influencia e (ou) modifica o funcionamento de determinadas instituições. $\mathrm{O}$ trabalho discute as estratégias políticas e os processos adaptativos dessa elite frente às instituições e em diferentes contextos políticos. 
gemônica na ciência política contemporânea (Hall; Taylor, 2003).

Ainda que seja relevante considerar a importância das instituições (e seus processos de transformação), outros elementos também devem ser utilizados nas análises políticas, especialmente uma reflexão sobre o tema das elites políticas que, como salientaram Marenco (2008) e Perissinoto e Codato (2008), embora tenha se configurado como uma preocupação central da ciência política no século XX, tem deixado de fazer parte de suas principais discussões. Segundo Marenco (2008), pode-se dizer, de maneira geral, que os estudos sobre elites políticas entraram num "beco sem saída", por centrarem seus esforços quase exclusivamente na conclusão de que as minorias governam, mesmo em democracias contemporâneas. Defendendo outras abordagens, o referido autor salienta que os estudos sobre a composição, recrutamento e circulação do interior de elites políticas oferecem bons indicadores para se compreender como as "instituições tornam-se instituições” (Marenco, 2008, p. 20).

Assim, as instituições, em grande medida, são também resultado das ações das elites políticas que, de um lado, contribuem para seus processos de transformação (Perissinoto, 2009), ao mesmo tempo em que são moldadas e bus$\overrightarrow{~ c a m ~ s e ~ a d a p t a r ~ a ̀ s ~ c h a m a d a s ~ r e g r a s ~ d o ~ j o g o . ~ A s ~}$ elites políticas podem ser entendidas como pessoas, partidos e grupos que estão no comando ou que têm influência sobre instâncias decisórias da política. Vistas de uma maneira ampla, elas constituem não só o pessoal de governo, mas as lideranças políticas e os grupos de influência que, em alguma medida, interferem na agenda política (Kaplan; Lasswell, 1984).

Em convergência com esses argumentos, este trabalho considera importante o estudo da relação entre elites e instituições e, nesse sentido, busca compreender como um ator, membro ou herdeiro de uma elite política longeva numa unidade subnacional, se move diante das regras do jogo democrático (frente a instituições e regras específicas, como o Le- gislativo em sua relação com o Executivo e os sistemas eleitoral e partidário) e em diferentes contextos das correlações de força (situação, oposição) dentro do cenário político estadual e federal.

As relações entre esses elementos serão avaliadas pari passu com as descrições e análises sobre essa trajetória. Nesse sentido, a seção que se segue aborda as características principais dessa elite e as dimensões de sua tradição.

\section{A TRADIÇÃO CARLISTA E A TRA- JETÓRIA DE ACM NETO}

"Carlismo" é um termo utilizado para designar o grupo formado no Estado da Bahia em torno da forte liderança de Antônio Carlos Magalhães que, durante algumas décadas, foi o político mais importante do Estado e um dos mais influentes do Brasil. Segundo Dantas Neto (2006a), deve-se pensar o carlismo não apenas como um grupo político, mas como uma "política", ou um modo de fazer política. Em sua interpretação, o carlismo constituiu-se como a versão baiana da modernização conservadora brasileira, isto é, uma versão regional de um mix de modernização econômica e conservadorismo político que, embora com variações de estilo e nas suas bases sociais, foi uma fórmula hegemônica na maior parte da história republicana brasileira, em diferentes regimes políticos.

A tradição carlista tem como característica fundamental um arranjo entre discursos e práticas, ao mesmo tempo modernizante e politicamente conservador. Do ponto de vista da modernização, o carlismo sempre se colocou como defensor das grandes linhas de desenvolvimento do capitalismo nacional, valorizando a gestão tecnocrática como meio de realização da estratégia modernizante. Já na perspectiva conservadora, tem uma compreensão de que a política deve ser exercida de maneira vertical, com a exaltação da necessidade de competência e da centralização da elite protagonis- 
ta, evitando-se, assim, os conflitos típicos do pluralismo político. Atrelado a essa estratégia mais prática, por assim dizer, o carlismo também se utilizou de elementos que compuseram um repertório simbólico ${ }^{3}$ muito específico, combinando a defesa da modernização - que conecta a elite estadual ao plano nacional - a uma forte ênfase no regionalismo político, por meio de um discurso de defesa dos "interesses da Bahia”. Assim, o carlismo, historicamente, construiu suas alianças político-partidárias de modo a fortalecer sua base local pela inserção no cenário nacional, geralmente alinhada à elite política governante. Além disso, foi central, em sua política, a força de um carisma, não só modernizante como autocrático, do líder realizador que sabe comandar, chamando a si, de modo vertical e personalista, a responsabilidade da direção política.

Nesse aspecto, a tradição carlista se configurou dentro do que Nunes (1997) definiu como "combinação" de gramáticas políticas. ${ }^{4}$ Conforme Dantas Neto (2006a), essa elite política, tendo sido condutora da modernização, mobilizou a gramática política do insulamento burocrático e, ao mesmo tempo e subsidiariamente, a do clientelismo. Outro elemento

\footnotetext{
${ }^{3}$ Este artigo aborda o repertório simbólico como uma dimensão do carlismo e o utiliza como um indicador importante de comparação entre as estratégias políticas de ACM Neto e a tradição carlista. Não é objetivo deste trabalho, entretanto, fazer uma discussão teórica dessa dimensão a partir de uma literatura do construtivismo, a partir da qual o carlismo seria uma ideia, uma espécie de paradigma político. O carlismo, neste trabalho, é entendido de maneira mais ampla, especialmente a partir dos estudos de Dantas Neto (2006a)
}

${ }^{4}$ Em sua análise sobre as "Gramáticas Políticas do Brasil”, Nunes (1997) opõe aquelas consideradas tradicionais às modernas e racionais. O clientelismo é a gramática política tradicional, marcada por uma troca generalizada que configura laços de dependência econômica e extraeconômica permanente entre atores sociais, sob uma base de relações pessoais características de sociedades camponesas. Essas práticas são transferidas para as associações, partidos políticos e instituições "modernas", daí o personalismo ter impregnado e engessado muitas dessas instituições. As três gramáticas "modernas" que fazem contraponto ao clientelismo no Brasil seriam o universalismo de procedimentos (que se baseia em normas impessoais e direitos iguais perante a lei para refrear e desafiar os favores pessoais), o insulamento burocrático (processo de proteção de núcleos técnicos do Estado contra a interferência do "público", ou seja, o Poder Legislativo ou organizações intermediárias) e o corporativismo, contraponto herdado da Era Vargas e que pretende fixar a participação corporativa de algumas classes nas decisões públicas como complemento e mesmo alternativa ao sistema representativo. conservador que acompanha a modernização - nesse caso, um elemento específico do carlismo e usado com mais força que o próprio clientelismo - é o regionalismo político, compreendido tanto pela defesa dos "interesses da Bahia", quanto pelo culto às "tradições baianas" (Pereira, 2007).

Partindo dessa compreensão geral do carlismo e considerando o peso dessa tradição, torna-se relevante compreender as transformações dessa elite a partir da reconstrução histórica das estratégias políticas do seu membro mais novo, ACM Neto.

Em 2002, quando se elegeu pela primeira vez deputado federal, ACM Neto tinha apenas três anos de vida política, vividos como assessor do Secretário Estadual de Educação. Nesse momento, segundo Dantas Neto (2010a), o carlismo já estava em processo de declínio, pois, desde 2001, ACM não comandava mais seu próprio grupo de modo unipessoal. As decisões mais importantes do grupo carlista já eram tomadas mediante tensões, conflitos e acordos políticos em sua cúpula. E se, nos últimos anos do regime militar e durante os anos 90, o carlismo era, por assim dizer, a elite política estadual e o grupo ocupava todo o espaço dessa elite dentro e fora do governo, desde, ao menos, o ano de 2001, já havia, na Bahia, um formato bipolar de competição política, tendo já despontado o PT (Partido dos Trabalhadores) como núcleo partidário aglutinador de um heterogêneo campo anticarlista. Também já fazia parte do passado o tempo em que os segmentos sociais de influência sobre o poder político, na Bahia, estavam quase todos articulados exclusivamente aos carlistas. Foi um tempo em que o senador ACM dirigia o grupo verticalmente, hierarquicamente, concentradamente, "personificadamente", apenas com a parceria de seu filho, Luís Eduardo Magalhães. Nos anos 2000, mesmo quando, afinal, fazia prevalecer suas posições, ACM ao menos teve de passar a considerar as posições de outros integrantes do grupo, como Paulo Souto, Antônio Imbassahy e José Carlos Aleluia. 
Embora em processo de declínio, o carlismo, em 2002, ainda se constituía como uma forte facção da elite regional, fato exemplificado pela vitória de seus candidatos a governador e para as duas vagas no Senado nas eleições daquele ano, quando ACM Neto, em sua primeira candidatura, foi eleito ${ }^{5}$ como o deputado federal mais votado do Estado.

Em 2006, o declínio do carlismo teve um momento crucial, marcado pela derrota de seus candidatos ao Governo do Estado (surpreendente, já que ele liderava com folga as pesquisas de intenção de voto) e ao Senado. Houve, nesse sentido, uma reconfiguração do arranjo das forças políticas na Bahia formando-se um novo cenário de competição política, com a crescente influência de Luís Inácio Lula da Silva, eleito presidente em 2002, e do PT na política baiana. ${ }^{6}$ Mesmo diante desse contexto, ACM Neto foi reeleito deputado federal e, mais uma vez, como o mais votado no Estado.

Em 2007, o carlismo perdeu seu líder mais importante. Lembra Dantas Neto (2007) que Antônio Carlos Magalhães morreu já fora do poder - em Brasília e na Bahia - e que seu espólio político passara a ser parcialmente gerenciado por seus correligionários ainda com ele em vida. A despeito desse refluxo A do grupo, em 2008, nas eleições municipais . para a Prefeitura de Salvador, ACM Neto li$\underset{8}{*}$ derou boa parte das eleições e foi o terceiro candidato mais votado, obtendo cerca de $27 \%$ dos votos válidos. O resultado das eleições municipais da Bahia, nesse ano, apon๙ิ tou para a conformação de uma "tripolarização” política, conformada pelas seguintes

○ ${ }^{5}$ Embora não apresentado nesse trabalho, em outra oportunidade a autora investigou detalhadamente o perfil elei-

$>$ toral de ACM Neto em 2002 e a relevância do espólio elei-

ธิ toral carlista para sua vitória nessa eleição (Pereira, 2014).

$\stackrel{\pi}{ }{ }^{6}$ A partir de 2002, o carlismo não mostrava mais ser, na eleição majoritária, uma facção da elite política com força - equivalente à de um partido predominante, ao molde de

IJ Sartori (1982). Já havia se instaurado uma competição po-

lítica bipolar, com o crescimento da força política do PT.

Àquela altura, a competição política, na Bahia, já era mais aderente ao tipicamente chamado sistema bipartidário, no qual dois partidos têm condições de competir com a possibilidade real de alternância do poder (Sartori, 1982). forças: o PT (ascendente desde 2002 e agora no Governo), o PFL, uma força tradicional, embora com peso abalado, e o PMDB, polarizado pela influência do então ministro da Integração Nacional, Geddel Vieira Lima (Dantas Neto, 2010b).

Os resultados das eleições de 2010 não confirmaram, para a política estadual, a tripolarização apontada pelas eleições municipais de 2008. Ao contrário, os resultados apontavam para a consolidação de nova situação dominante na política baiana, agora conformada em torno do PT (Dantas Neto, 2010a). Nesse contexto de consolidação da força política de Lula e do PT no Brasil e na Bahia (com a reeleição do governador e a vitória dos dois candidatos a senador da coligação, além da eleição de Dilma Rousseff, sucessora de Lula), ACM Neto, embora tenha perdido cerca de 100 mil votos, foi mais uma vez o deputado federal mais votado do Estado.

Em 2012, ACM Neto candidatou-se novamente a prefeito de Salvador, colocando-se como oposição ao governador Jaques Wagner, em um momento em que a gestão do PT, no Estado, nas pesquisas, era mal avaliada pelos soteropolitanos. Elegeu-se no segundo turno com esse mote principal e também por fatores outros, conforme se verá melhor na análise de seus discursos e apelos de campanha.

Em 2016, já num contexto de crise política no cenário nacional e de grande enfraquecimento do PT, ACM Neto se reelegeu no primeiro turno, obtendo mais de $70 \%$ dos votos em todas as zonas eleitorais da capital baiana. A trajetória ascendente desse ator político, mesmo frente ao contexto de declínio de seu grupo, evidenciou, mais uma vez, sua importância no cenário baiano, fazendo surgir o debate sobre a continuidade ou não do carlismo tendo como ator político central, agora, ACM Neto.

Nesse sentido, as próximas seções tratam dessa questão, analisando suas estratégias políticas ao longo desse período. 


\section{AS ESTRATÉGIAS POLÍTICAS DE ACM NETO}

\section{Atuação Parlamentar}

ACM Neto foi eleito três vezes deputado federal, exercendo mandato de 2003 a 2012 quando renunciou para assumir a Prefeitura Municipal de Salvador em 2013. Durante esse período, participou de várias comissões regulares na Câmara de Deputados, além de comissões parlamentares de inquérito (CPIs); foi eleito segundo Vice-Presidente e Corregedor da Câmara de Deputados; também foi líder do PFL e, posteriormente, do DEM; ${ }^{7}$ apresentou diversas Emendas ao Orçamento e alguns Projetos de Lei, atuando sempre com uma postura de oposição decidida ao Governo Federal, além de ter um discurso enfático em defesa dos "interesses da Bahia".

Mantendo o foco na relação com a tradição carlista, o trabalho analisará, nesta seção, a atividade parlamentar de ACM Neto, principalmente a partir de seus discursos em plenário. ${ }^{8}$ Ao longo do período em que foi deputado, foram contabilizados 1071 discursos de ACM Neto em plenário, taquigrafados e disponibilizados pela Câmara dos Deputados. Tais pronunciamentos ocorreram em diversas modalidades de sessões: ordinárias, extraordinárias, não deliberativas, etc., todas elas englobadas nesta análise.

A sistematização dos pronunciamentos foi feita a partir de recorrências temáticas. Os

\footnotetext{
${ }^{7}$ O DEM foi fundado em 28 de marçode2007, em substituição ao Partido da Frente Liberal (PFL).

${ }^{8}$ Ao longo dos mandatos, apresentou também 14 Projetos de Lei, um de Lei Complementar e um de Emenda Constitucional. Como todos, exceto um, foram amplamente discutidos ou defendidos em plenário, optou-se por tratar deles através dos discursos e não como atividade parlamentar em separado. É o caso da PEC 213/2003, que proíbe a edição de MP para criação e majoração de impostos, tema frequente do deputado; ou o PL 1233/2003, que dispõe sobre isenção do IPI na aquisição de automóveis para utilização no transporte autônomo de passageiros, de pessoas portadoras de deficiência física e os destinados ao transporte escolar. Este trabalho não apresenta as estratégias políticas de ACM Neto a partir de suas Emendas Orçamentárias, porque elas foram cotejadas em relação à geografia de seu voto e analisadas em outra oportunidade (Pereira, 2014).
}

temas mais frequentes nos pronunciamentos foram listados e, posteriormente, agrupados. $\mathrm{O}$ agrupamento dos itens em blocos combinou esse critério de regularidades com interesses da própria pesquisa, ou seja, levou em consideração também os temas recorrentes da tradição carlista. Os temas possuem profunda relação entre si, de modo que, muitas vezes, temas de blocos diferentes estiveram vinculados na fala do deputado e em sua própria atuação.

Dessa forma, o conteúdo dos 1071 pronunciamentos foi examinado e posteriormente sistematizado em doze itens temáticos que, por sua vez, foram agregados em dois grandes blocos, conforme é apresentado no Quadro 1, a seguir. Tais temas serão analisados, em ordem temporal, de modo correspondente a cada um de seus três mandatos.

Quadro 1 - Temas dos discursos em plenário do Deputado ACM Neto, 2003-2012

\section{I - Temas gerais, nacionai}

1. Funcionamento das Instituições (Pacto federativo e Relação entre os três poderes)

2. Corrupção e ética pública

3. Gestão e administração pública federal

4. Temas econômicos, fiscais e tributários (inclusive reforma tributária)

5. Outras reformas (previdenciária e política)

6. Políticas públicas (educação, saúde, segurança, transporte, infraestrutura, salário mínimo, etc.)

7. Outros (homenagens, questões internacionais, questões ligadas à juventude e outras categorias, etc.)

II- Temas Estaduais, regionais

1. Defesa do modelo de gestão carlista

2. Demanda por recursos do Governo Federal (Nordeste e Bahia)

3. Críticas à gestão petista na Bahia

4. Referências a municípios baianos

5. História, cultura baiana

Fonte: Elaborado pela autora.

No seu primeiro mandato, entre $2002 \mathrm{e}$ 2006, ACM Neto esteve na oposição no âmbito nacional. Em âmbito estadual, integrava o grupo político do Governador da Bahia, Paulo Souto, e, até 2004, também o do prefeito de Salvador, Antônio Imbassahy. Tal situação diferenciou sua atuação parlamentar nesse primeiro mandato dos outros dois, nos quais esteve na oposição em todos os níveis. Em seus discursos, os principais temas mobilizados referiram-se ao Bloco I, que representou 79,2\% 
dos seus eventos de fala. ${ }^{9}$ Dentre esses, quatro temas específicos, destacaram-se: Temas econômicos, política fiscal e tributária $(24,2 \%)$, Políticas públicas (15,38\%), gestão e administração pública federal $(13,68 \%)$ e Funcionamento das instituições $(11,97 \%)$.

Durante esse mandato, exerceu um papel destacado de oposição, voltando suas críticas à administração pública federal no que concerne a um conjunto de questões, como cortes ao orçamento para a área de infraestrutura, criação de cargos públicos e ao que chamou de "aparelhamento da máquina pública" pelo PT. Tal crítica costumeira aproxima a atuação do deputado de uma característica importante do tradicional discurso carlista, a defesa de que os cargos políticos sejam ocupados por quadros técnicos e não por indicações ideológicas ou partidárias.

O Bloco Temático II, referente aos temas estaduais e regionais, representou 20,8\% dos eventos de fala nesse mandato. De saída, essa incidência relativamente baixa revela que ele foi um deputado bastante absorvido por temas nacionais, sem correr risco de se tornar um parlamentar paroquial. Mas, por outro lado, em momento de efervescência e em face das responsabilidades de representação da bancada, o fato de dedicar uma a cada cinco falas suas a temas regionais e estaduais mostra que tampouco i. foi um deputado desconectado dos problemas da base geográfica de sua votação. Ainda que menos mobilizados, os temas desse bloco são relevantes uma vez que a questão do desenvolvimento regional, sendo uma marca qualitativa ๙ forte de seus discursos, é uma das que mais per$\therefore$ mitem identificar conexões entre a estratégia $\infty$

$>$ deles tiveram de ser alocados simultaneamente em dois

ثิ ou mais itens, já que muitos discursos abordavam mais de

- um tema. Por isso, embora tenham sido coletados e estu-

$\stackrel{\pi}{\geq}$ dados 1071 pronunciamentos, o universo total compõe-se

స్ de 1386 "eventos de fala", isto é, a abordagem de um tema

num pronunciamento. Logo, um mesmo pronunciamento

I pode conter mais de um tema e alocado, como conjunto

de eventos de fala, em mais de um bloco temático. Por

ser tratar de uma análise que percorreu discursos longos,

proferidos durante uma década de atividade parlamentar,

optou-se por uma sistematização dos principais temas

abordados e uma análise de seus significados. da tradição carlista. Nesse Bloco, destacaram-se eventos de falas que demandaram mais recursos do Governo Federal para a Bahia, em especial para o metrô de Salvador (8,55\%), e aquelas que enfatizaram a gestão carlista na Bahia como um exemplo a ser seguido (com ênfases tanto na de Paulo Souto, governador, quanto na de Imbassahy, prefeito de Salvador - 5,41\%), tomando a defesa de políticos carlistas em geral e do tipo de política que praticam.

Essa seleção de temas permanece no segundo mandato, quando falas alocadas no Bloco I representaram 86,8\%. Agora, entre os temas nacionais e gerais desse bloco, os mais presentes nas falas de ACM Neto foram os ligados ao item "funcionamento das instituições", com $23,2 \%$ de incidência sobre o total dos eventos de fala daquele mandato. Dentro desse item, permanece relevante o tema do pacto federativo, relacionado à necessidade de se repensarem os deveres e obrigações dos entes federados e, mais especificamente, à defesa da autonomia dos municípios. Porém, dessa vez, a maioria das 130 falas agrupadas nesse item temático versou sobre a relação entre os três poderes. Por certo, em virtude da sua nova condição de líder do DEM, centrou fogo na acusação de que o Executivo tentava rebaixar o papel do Poder Legislativo.

No Bloco Temático II, que representou $13,2 \%$ do total dos eventos de fala no segundo mandato, apareceu com maior percentual $(4,6 \%)$ o item referente à demanda de recursos para Bahia e para o desenvolvimento do Nordeste. Nesse aspecto, destacou-se novamente a defesa de que o Governo Federal enviasse recursos para a obra do Metrô de Salvador, persistência que guarda uma evidente relação com a candidatura do deputado a prefeito da capital baiana nas eleições municipais de 2008. Apareceu novamente o "apelo" de que essa reivindicação não se resumisse à demanda de um partido ou a uma questão ideológica, mas que fosse uma "briga em defesa da Bahia", mais uma entre várias evidências de presença, nas falas de ACM Neto, do viés regionalista 
forte da tradição carlista.

Ao longo dos anos do segundo mandato, a proporção entre os pesos dos dois blocos temáticos variou consideravelmente. É possível dizer que ACM Neto mobilizou sua atuação parlamentar tendo, entre suas referências, os momentos eleitorais de 2008 e 2010 . No entanto, a disputa para prefeito parece ter afetado menos sua atuação parlamentar do que a campanha à reeleição para deputado federal em 2010. A Bahia, como repertório simbólico, foi mais valorizada na condição de base geográfica de votação do que como referência simbólica passível de uso no pleito municipal.

No seu terceiro mandato - ao qual renunciou para assumir o cargo de prefeito de Salvador para o qual fora eleito no final de 2012 -, o deputado ACM Neto colocou-se, uma vez mais, como oposição nas esferas federal e estadual, com atuação parlamentar bastante contundente na crítica aos dois níveis de governo. Voltou, inclusive, à liderança da bancada do DEM por dois anos, a partir de fevereiro de 2011, até o último dia em que esteve na Câmara.

Assim como nos dois primeiros mandatos, os temas que apareceram com maior incidência foram os do Bloco I $(87,3 \%)$, mas agora, sobretudo aqueles que se referiram ao item "gestão e administração pública federal”, enquanto o item "funcionamento das instituições”, que liderara no mandato anterior, recuou. Foi o item temático que mais peso relativo perdeu, seguido do item "outras reformas". Enquanto isso, os pesos relativos dos itens "políticas públicas" e "corrupção e ética pública” praticamente dobraram seus pesos relativos no terceiro mandato. Embora possa se atribuir essa inflexão ao exercício continuado da liderança da bancada de um partido de oposição, ela também expressa um claro trânsito pragmático do deputado do mundo da polity (das instituições) para o da politics (onde ressalta o tema da ética) e policies. Essa é uma primeira e abrangente observação, a indicar que, no terceiro mandato, a estratégia política de ACM Neto aproximou-se como nunca do perfil pragmático da tradição carlista.

Ao contrário do que ocorreu com o Bloco I (no qual itens temáticos apresentaram avanços ou recuos às vezes drásticos), nesse Bloco II, na comparação entre os dois mandatos, a estabilidade dos pesos foi a regra. O regionalismo político e o “amor pela Bahia” expressaram-se novamente associados às críticas à gestão petista na Bahia e à referência à perda da importância do Estado no Brasil, mesmo nas condições favoráveis de o governo do estado ser do mesmo grupo político do governo federal, condição extremamente valorizada pela prática carlista ao longo dos anos.

Embora a incidência de temas estaduais e regionais tenha se mantido estável no segundo $(13,2 \%)$ e no terceiro mandatos $(12,7 \%)$, entre os anos de 2011 e 2012 (ou seja, no decorrer do terceiro mandato), esse peso aumentou. Parece que, dessa vez, o fato se ligou às eleições municipais de 2012, o que demonstra, na atuação parlamentar de ACM Neto, uma estratégia política claramente voltada para ao pleito municipal da capital.

Conforme se observa na tabela-síntese abaixo, a predominância de temas nacionais e gerais sobre questões regionais e baianas na atuação parlamentar de ACM Neto é uma constante nos três mandatos, mas é menos expressiva no primeiro do que nos dois seguintes.

Durante os seus três mandatos, ainda que os temas sobre a Bahia tenham permanecido nos pronunciamentos, assim como a ênfase

Tabela 1 - ACM Neto: discursos em plenário, por mandato

\begin{tabular}{l|c|c|c|c|c|c}
\hline \multirow{2}{*}{ TEMAS } & \multicolumn{2}{|c|}{$1^{\circ}$ mandato } & \multicolumn{2}{c|}{$2^{\circ}$ mandato } & \multicolumn{2}{c}{$\begin{array}{c}3^{\circ} \text { mandato } \\
\text { (até 2012) }\end{array}$} \\
\cline { 2 - 7 } & $\mathrm{N}$ & $\%$ & $\mathrm{~N}$ & $\%$ & $\mathrm{~N}$ & $\%$ \\
\hline I - Temas gerais e nacionais & 278 & 79,2 & 486 & 86,8 & 200 & 87,3 \\
\hline II - Temas estaduais e regionais & 73 & 20,8 & 74 & 13,2 & 29 & 12,7 \\
\hline TOTAL DE EVENTOS DE FALA & 351 & 100 & 560 & 100 & 229 & 100 \\
\hline
\end{tabular}

Fonte: elaborado pela autora. 
discursiva dada a essa questão, gradativamente o deputado ganha espaço nacional dentro do seu partido e no próprio Congresso.

Ao longo desse período, ACM Neto se tornou líder do DEM e referência nacional da oposição, mantendo a tradição do carlismo de não se configurar apenas como uma elite local, mas com profundos vínculos nacionais. Porém isso não significou que o deputado tenha deixado de mobilizar discursos ligados aos temas estaduais e regionais. Considerando esse conjunto, a avaliação de sua atuação parlamentar exclui a possibilidade de identificá-lo como um parlamentar paroquial, mas, ao mesmo tempo, sua ênfase nos temas regionais demonstrou sua preocupação em se manter conectado à base geográfica de sua votação. Essa combinação entre dois planos (o nacional e o estadual) na atuação de ACM Neto, como deputado federal, é um dos nexos mais fortes entre a sua estratégia política e a tradição carlista. Foi essa combinação, efetivada quase sempre com êxito, tanto em tempos de ditadura quanto de democracia, que Dantas Neto (2006a) apontou como principal fator da longevidade da liderança pessoal de ACM e da hegemonia carlista sobre a política baiana, por isso nomeando a fase mais longa da trajetória do carlismo (que se estendeu da segunda metaA de dos anos 70 até o final dos 90) de "carlismo . baiano-nacional".

Por outro lado, uma das marcas da atuação parlamentar de ACM Neto foi seu destacado papel na oposição federal nos três mandatos e também ao governo estadual, nos últimos dois. Tal estratégia demonstrou proximidades e diferenças em relação à tradição carlista. Uma proximidade notável se dá quando ACM Neto se mantém, na política nacional, no mesmo campo político em que o carlismo, tendo à frente ACM e Luís Eduardo Magalhães, construiu suas alianças na década dos 90. Porém, em razão da opção majoritária do eleitorado brasileiro em favor do PT, ACM Neto se viu numa curiosa situação: para manter o alinhamento ao mesmo campo político de seu avô e seu tio, ele precisou romper com outra forte tradição carlista: a de procurar sempre seguir uma linha política governista, no plano federal. Especialmente em sua fase "baiano-nacional”, enquanto manejava com habilidade os fluxos de recursos materiais e políticos que, por sua influência, partiam do centro político do País para a Bahia, em contrapartida, garantia a esse centro político o conforto do apoio de uma elite estadual altamente estabilizada.

Ao lado dessa constante, foi possível observar aspectos variáveis a cada um dos mandatos, variações que se davam conforme distintos contextos e suaves inflexões em sua estratégia. No primeiro mandato, evidenciou-se, de maneira especial, um traço importante da tradição carlista: a valorização, por assim dizer, ideológica, da elite estadual, colocando-a num patamar político acima do partido nacional, assim como o elogio do padrão de gestão administrativa praticado por essa elite. Foi possível ver como essa atitude diminui ao final do primeiro mandato e durante o segundo - quando ainda não havia assumido a liderança incontestável de seu grupo, que passara à oposição na Bahia - para ser retomada no terceiro mandato, após a consolidação dessa liderança. Por outro lado, na medida em que ganhava maior relevância política, entra em cena, como traço que o diferencia da tradição carlista, a defesa intransigente do seu partido no nível nacional, utilizando a liderança do DEM na Câmara como importante estratégia para galgar visibilidade fora da Bahia. Assim, desde o segundo mandato, ACM Neto se esforçou para se colocar num papel de negociador relevante das demandas da oposição.

Em termos do repertório simbólico, permanecem elementos similares aos da tradição carlista: o regionalismo político, o apelo modernizante, a defesa do insulamento burocrático, associada à ação do líder realizador, imagem que é perpassada por outros conceitos caros à tradição carlista, como o protagonismo da elite governante e a importância da autoridade na solução, pelo líder, dos problemas 
da política. Sobre esses quatro pontos, é importante relembrar o que se destacou ao longo desta seção: que neles se concentrou boa parte das críticas às gestões petistas, tanto no nível federal quanto estadual. Por fim, elemento clássico da tradição carlista, esteve muito presente a crítica à corrupção, associada não tanto a uma ética de vida pública, mas à "moralidade” do homem público, no que, mais uma vez, se mostra a defesa prática do protagonismo da elite governante, de cuja qualidade a prosperidade do País e a felicidade do povo dependem mais do que do formato das instituições.

Tais características de aproximação e distanciamento apareceram também nos discursos e apelos de campanha mobilizados por ACM Neto, como se verá na próxima seção.

\section{Discursos e apelos de campanha}

A estratégia política de ACM Neto será analisada, nesta seção, tendo como foco as campanhas eleitorais de que participou como candidato, entre 2002 e 2016. Compreendem, além de suas três candidaturas a Deputado Federal (2002, 2006 e 2010), as três candidaturas a Prefeito de Salvador, em 2008 (quando ficou em terceiro lugar), em 2012 e 2016, quando se elegeu.

Embora também se pretenda apontar elementos que, nessas campanhas, indiquem uma política de alianças, a abordagem central tem como foco o repertório simbólico de ACM Neto mobilizado em seus discursos e declarações de campanha, bem como em peças publicitárias, para analisá-lo em perspectiva de comparação com o da tradição carlista. O intuito é analisar:

- a construção de imagem;

- a formulação de um discurso político;

- uma agenda de decisões que leva a apoios dentro e fora do partido e à definição de políticas de alianças.

Será adotado, como método de exposição, analisar, em princípio, as campanhas legislativas e, posteriormente, as voltadas ao
Executivo Municipal. Conforme se observará mais adiante, diferenças entre discursos e apelos de campanha, assim como entre apoios e alianças neles refletidos, fundamentam-se mais nas diferentes características de eleições majoritárias e proporcionais do que numa lógica temporal que possa indicar inflexões de trajetória. Assim, por exemplo, será mais fácil encontrar semelhanças entre as estratégias de ACM Neto em 2006 e 2010, do que entre 2008 e 2010, e assim por diante.

\section{As campanhas para Deputado Federal (2002, 2006 e 2012)}

No escassíssimo material jornalístico encontrado sobre as eleições de $2002^{10}$, foi possível perceber que a campanha de ACM Neto foi marcada, por assim dizer, como uma "iniciação" na política eleitoral, uma espécie de "apresentação" sua aos prefeitos e a outras lideranças locais. O modus operandi predominante na campanha foram comícios e visitas do candidato a diversos municípios, ao lado de - e secundando - lideranças do carlismo. Destacam-se suas visitas a municípios que eram redutos eleitorais carlistas acompanhadas por representantes mais proeminentes de cada local, que, posteriormente, compuseram o grupo de concentração da sua votação (Pereira, 2014). Ao longo da campanha para essa eleição, ficou claro o forte investimento do grupo carlista para a eleição de ACM Neto.

Após seu primeiro mandato como deputado federal, nas eleições de 2006, ACM Neto já se apresentava como um candidato com mais autonomia nas decisões sobre alianças eleitorais e com posicionamentos mais firmes, o que não impediu, de outro lado, que continuasse "se promovendo" junto ao grupo carlista. Tornou-se mais claro, nessa campanha, que ACM

${ }^{10}$ A escassez ainda maior no caso específico desse pleito talvez se relacione ao fato de que se tratava, ainda, de um político desconhecido, sem expressão própria. Conforme se observará mais adiante, não raro ACM Neto foi apresentado como "mais um" familiar de político tradicional que seguia sua trajetória, utilizando-se do espólio político. 
Neto não era mais visto apenas como familiar de um político tradicional, mas se apresentava explicitamente como parte de uma elite política e assim já era considerado. Essa sua posição ficou bastante evidenciada na derrota do candidato carlista, Paulo Souto, ao governo do Estado. ACM Neto, mais uma vez, se mostrou como parte de um grupo e evidenciou seu papel na oposição estadual, conforme ilustra o trecho de discurso abaixo transcrito:

O PFL vai continuar trabalhando forte pelo Estado, na Câmara, na Assembleia, temos dois senadores, elegemos deputados federais e estaduais. Temos ainda um grande número de prefeitos na Bahia. O partido não vai desanimar, pelo contrário, agora é que colocamos em prática a capacidade de reagir [...] não torço pelo insucesso do novo governador, mas nós exerceremos oposição ao governo da Bahia, coisa que venho 'treinando’ em Brasília. O fato de sermos oposição no plano nacional facilita, agora temos know-how de oposição, seremos uma oposição responsável, mas fiscalizadora (Vasconcelos, 2006, p. 11)

As táticas publicitárias que compuseram a estratégia de ACM Neto, entretanto, não se resumiram a proclamar seu vínculo direto com o grupo. Em uma das poucas peças publicitárias encontradas da sua campanha às eleições de 2006, o texto enaltecia três elementos importantes de seu primeiro mandato: a "moralidade e a ética", a "atuação nos temas nacioકิ nais" e a "defesa da Bahia”. Assim, ao longo $\therefore$ do período eleitoral de 2006, ACM Neto seguiu construindo sua imagem ligada ao grupo carlista, mas agora com maior autonomia, tendo em vista, também e, sobretudo, sua experiência na Câmara dos Deputados.

i.

$\infty$

Ao longo do período de 2006 a 2010, algumas mudanças alteraram o panorama político nacional e estadual: a derrota do carlismo ao governo do Estado em 2006 e a morte de ACM em 2007, para além do crescimento da influência do PT na política baiana. Por isso, em muitos momentos, a tônica da campanha eleitoral de 2010 dada pelos meios de comunicação foi pautada na volta ou não do carlismo. Em matéria intitulada "O renascer do carlismo", no Jornal A tarde de 11 de abril de 2010, ACM Neto diz estar se preparando para entrar firme na campanha com um discurso bem definido: a defesa do legado do avô, o ex-senador Antônio Carlos Magalhães. Segundo a matéria, ACM Neto estava estudando e reunindo informações para ir a campo fazer o resgate do carlismo e dar uma resposta aos que diziam que ele havia morrido. Diante dessa estratégia, afirmou o deputado: "Vamos fazer o comparativo entre o que foi a Bahia no tempo de ACM e o que é hoje nos dias de Wagner. E vamos ganhar". Em 20 de abril de 2010, o próprio ACM Neto escreveu uma matéria no Jornal A Tarde intitulada "A Bahia do presente sente falta de ACM", que revela muito sobre esse mesmo cenário. Transcreve-se, a seguir, parte desse texto:

Antônio Carlos Magalhães criou o carlismo por suas características pessoais e com as virtudes de líder, de grande político e administrador público, de homem visionário, à frente do seu tempo, que modernizou a Bahia em todos os aspectos. As características pessoais se foram com sua morte. [...] Já as características do administrador, do político de envergadura nacional, [...] permanecem mais vivas do que nunca. O homem se foi, mas seus ideais ainda nos inspiram. Até sua morte, ACM carregou a bandeira da luta incansável pela Bahia, do amor sem limites pelo povo de sua terra, da seriedade no trato com o dinheiro público, do pulso firme no combate à criminalidade, do olhar sempre atento e vigilante aos mais pobres, além de formar os melhores quadros da política baiana. [...]. Se esses ideais estão vivos em todas as pessoas que querem uma Bahia melhor, então, o carlismo vive bem. O carlismo está mais forte do que nunca, porque a fraqueza e a incompetência do governo Wagner só aumentam as saudades de ACM. Wagner é tão condescendente com os outros estados nordestinos na disputa por empregos e desenvolvimento, que hoje, certamente, é mais 'importante' para Pernambuco do que para a Bahia, porque sua omissão fez a Bahia perder o protagonismo do desenvolvimento do Nordeste. [...]. Wagner [...] é amigo do presidente, mas não tem prestígio para conseguir verbas necessárias ao desenvolvimento da Bahia. Então, pergunto: como não sentir saudade daquele que colocava a Bahia como a razão de sua vida? ACM está no coração de todos os baianos que perderam as esperanças, [...] 
O PT não conseguirá matar o carlismo porque a Bahia é livre. Livre para tudo. Inclusive para amar sem patrulhamento seus filhos preferidos, como Mãe Menininha, João Ubaldo, Caetano, ACM, Jorge Amado, Irmã Dulce [...] ACM ajudou no processo de redemocratização que levou Tancredo Neves ao poder - um ato de coragem. E contribuiu muito na eleição de Fernando Henrique Cardoso. [...] Como neto de Antônio Carlos Magalhães, posso dizer que aprendi muito. Esse aprendizado ajuda em minha trajetória política em todos os momentos. Mas recebi dele também uma benção hereditária, uma 'herança bendita'; vem do berço o meu amor pela Bahia e a força para lutar pelo meu Estado. ACM viveu um verdadeiro caso de amor com os baianos. Melhor, viveu um casamento próspero, apaixonado, um casamento eterno (Magalhães Neto, 2010).

Na matéria acima, ACM Neto apresenta elementos importantes do repertório simbólico da política carlista, como, por exemplo, sua face modernizadora, seu perfil de liderança e de administrador, sua envergadura nacional, sua defesa do desenvolvimento regional, o enaltecimento cultural através do amor e do culto a seus filhos ilustres e, o mais evidente, o discurso de "amor pela Bahia". Mais que isso, a sua "luta incansável" pelos interesses da Bahia, pela qual, como diz o deputado, ele era capaz de "mostrar os dentes". Ademais nota-se, nesse discurso, a acusação de "condescendência” de Wagner para com os outros estados nordestinos, o que exprime a percepção clássica do carlismo dos anos 80 e 90 de que a Bahia se diferencia do Nordeste. Nesse aspecto, o carlismo usava instrumentalmente o discurso nordestino quando precisava de apoio na região para algum pleito junto ao Governo Federal, mas, no fundo, via os estados vizinhos como concorrentes, já que buscava sempre o destaque da Bahia no cenário nacional. Também em proximidade com a tradição carlista, encontram-se, nesse discurso do então deputado, uma alusão à capacidade de a elite carlista formar quadros políticos qualificados, o que remete a uma característica amplamente defendida pelo grupo, o insulamento burocrático (Nunes, 1997).

Tal pronunciamento evidencia, ainda, a partir do enaltecimento das características atribuídas a ACM, que o deputado utilizou como apelo de campanha a ideia de que a Bahia governada por Wagner sente falta desses elementos. Dessa forma, afirmava que, como neto do senador, aprendeu muito e se colocou como alternativa como político, sobretudo como defensor da Bahia, afirmando que o baiano é livre para escolher qual das "duas Bahias" é melhor, se a de ACM ou a de Wagner. Conforme se observa, fica claro, nessa campanha, que ACM Neto se utiliza desse repertório simbólico mobilizando toda a base tradicional carlista, além daqueles eleitores que estavam insatisfeitos com a gestão petista de Wagner.

Outro ponto importante da estratégia da campanha eleitoral de 2010 foi o que o deputado chamou de "sincretismo político", isto é, os apoios que deu ou recebeu de candidatos ao Legislativo estadual, cujos partidos, em vários casos, compunham outras coligações para as eleições majoritárias. É preciso entender as chamadas "dobradinhas" não apenas como táticas de otimização pragmática de votos para ACM Neto, mas também como uma estratégia que, ao garantir o apoio, como personalidade política, a candidatos a deputado estadual, se pautava na possibilidade de estabelecer relações políticas para o futuro, capazes de cortar transversalmente vários partidos quando ACM Neto necessitasse de apoio para pretensões a cargos majoritários. Como efeito colateral dessa ampliação da sua base, houve o enfraquecimento eleitoral de quadros tradicionais do PFL e DEM na Assembleia Legislativa, cujos redutos passaram a ser visitados por candidatos estranhos ao partido, para lá levados por Neto. Esse último manteve, além disso, razoável distância das campanhas dos candidatos majoritários do DEM para se dedicar à sua própria. Tanto essa tática como a das dobradinhas heterodoxas tornaram-se elementos agravantes da perda de substância eleitoral do DEM.

É possível compreender a estratégia eleitoral de ACM Neto em 2010 como, por um lado, um resgate do carlismo, ao buscar man- 
ter parte dos seus eleitores mais tradicionais a salvo dos efeitos da cooptação de quadros ex-carlistas pelo governo petista, e, por outro, um voo solo, com o qual agregou novas parcelas do eleitorado a seu perfil eleitoral, por meio de um discurso renovado e de dobradinhas heterodoxas. Essa combinação talvez possa explicar a grande votação de ACM Neto, reeleito, mais uma vez, como o mais votado do Estado. E significa que, se o DEM já não tinha grande estrutura partidária e passou a ter uma menor ainda após aquelas eleições, por outro lado, passou a contar, além desse espólio eleitoral enfraquecido da elite carlista, com a liderança forte de ACM Neto.

\section{As campanhas de ACM Neto para Prefeito de Salvador (2008 e 2012)}

Tais características gerais dos discursos e apelos de campanha de ACM Neto se mantêm, em parte, nas campanhas majoritárias. Porém a diferença na estrutura institucional dos pleitos promoveu também algumas inflexões. A maneira como ACM Neto se relacionou diretamente com a política carlista, em sua primeira campanha para prefeito em 2008, foi bastante peculiar e bem diferente do que ocorreu $\neg$ em eleições proporcionais, especialmente porque, como foi salientado anteriormente, nesse momento o carlismo perdeu parte expressiva de seu poder. Apontado criticamente pelos adversários, sobretudo por Jaques Wagner e Geddel Vieira Lima, como o herdeiro do carlismo, nessa primeira eleição, depois da morte de ACM, ele teve uma postura cuidadosa ao falar do avô e do grupo político. Logo no início da campanha frisou: "Quanto ao espólio carlista, o grupo passa por grande processo de transformação. Existem marcas importantes desse grupo que devem ser preservadas e servem de exemplo, o que não quer dizer que se espere do momento de hoje o que foi o passado" (Rocha, 2008b, p. 6). Nesse sentido, sua estratégia foi, de um lado, não deixar de considerar o que o grupo fez de importante (especialmente sua ênfase na moralidade e na ética públicas), e, de outro, colocar-se como algo novo, distante do passado, porque "os tempos são outros" e porque a política feita pelo seu avô não poderia mais ser feita por ele da mesma forma. Ou seja, claramente, ele utiliza como estratégia de campanha o afastamento do lugar de herdeiro do carlismo e se coloca como político jovem.

No primeiro dia do seu HGPE na TV, ACM Neto utilizou uma declaração do ex-senador, que dissera que ele entrara na Câmara como seu neto e passara, com a sua atuação, a uma nova condição, de modo que ACM passara a ser conhecido como o avô de ACM Neto, invertendo-se a referência.

Quanto à votação, propriamente, ACM Neto ficou em terceiro lugar na eleição, com cerca de $27 \%$ dos votos, e, no segundo turno, apoiou João Henrique (PMDB), mesmo sendo ele aliado de Geddel Viera Lima, ${ }^{11}$ antigo adversário histórico de ACM. Quanto a essa questão, Neto disse que sempre manteve diálogo com ele, mesmo quando seu avô era vivo, destacando suas diferenças: "As minhas relações são as minhas relações. Eu entendo que o senador ACM marcou a política da Bahia. Mas o momento hoje é de diálogo entre várias correntes” (Rocha, 2008a, p. 8). Assim, fica evidente a ideia do carlismo como algo datado, que deveria ser superado (mantendo seus elementos positivos). Para essa superação, ACM Neto se coloca como um político que, sendo jovem, mas experiente, é capaz de realizá-la.

Essa estratégia se desenvolveu diante de um contexto em que o carlismo se encontrava bastante enfraquecido e diante do fato de Salvador ser considerado, historicamente, um município "anticarlista”, o que exigiu do candidato fazer uma campanha mobilizando diversos setores da sociedade. ${ }^{11}$ Importante lembrar, nesse aspecto, que a relação de Ge-
ddel e do PMDB com a base carlista foi construída através
de Luís Eduardo Magalhães em meados dos anos 90 e con-
tinuou quando ele morreu, tendo o novo rompimento só
se dado por volta dos anos 2000. Desse modo, o diálogo
com Geddel, nessas eleições, não se configurou como algo
que se contrapôs de modo tão claro à tradição do carlismo. 
Estudos sobre as eleições de 2008 mostram que o contexto econômico positivo do governo Lula favoreceu que fossem evitados ataques à administração nacional. Assim, os candidatos a prefeito ligados ao poder federal destacaram o crescimento econômico e a expansão de benefícios sociais, e os candidatos da oposição tentaram municipalizar as eleições, concentrando-se em questões locais. Já em 2012, em um contexto marcado por uma grande insatisfação com a administração federal, muitos candidatos a prefeito criticaram o continuísmo. Isso culminou em uma maior fragmentação e maior renovação nas prefeituras (Lavareda; Telles, 2016).

Nesse contexto, diferentemente das eleições de 2008, as eleições municipais de Salvador foram marcadas por uma polarização muito evidente, caracterizada por trocas agressivas de críticas entre ACM Neto e o candidato do PT, Nelson Pelegrino.

ACM Neto se colocou mais como candidato da oposição ao governo estadual e menos como de oposição ao prefeito, tendo como apelo central ser do grupo contrário a Jaques Wagner e a seu candidato. Esses elementos são importantes porque ACM Neto conseguiu vencer o pleito municipal porque sobrepujou o PT na construção de uma imagem de mudança na Prefeitura, à medida que se firmou como oposição a "tudo o que aí está", estratégia contrária à do PT que focou no discurso do alinhamento político total, entre os governos Federal, Estadual e Municipal.

É interessante notar que ACM Neto foi, ao longo de toda campanha, mas, principalmente, no segundo turno realizado entre ele e Nelson Pelegrino ${ }^{12}$, associado ao grupo carlista e aos dezesseis anos de governo desse grupo no estado. No entanto, comparada à incidência com que ocorrera nas eleições de 2008, a temática sobre a volta ou não do carlismo não

${ }^{12}$ No segundo turno, os candidatos Mário Kertész (que se desfiliou do PMDB) e Márcio Marinho (PRB) apoiaram Nelson Pelegrino, e Nestor Neto (PMDB), candidato a vice-prefeito na chapa do PMDB, assim como outras lideranças desse partido, como Geddel Vieira Lima, apoiaram ACM Neto. se configurou como tema central dessa campanha, mesmo sendo mobilizada por diversas peças publicitárias do PT e mesmo tendo sido um dos eixos do lançamento da sua própria campanha.

Ao final, ACM Neto sagrou-se o novo prefeito eleito de Salvador. Seu forte posicionamento contra o governo estadual foi um elemento central para a sua vitória, uma vez que a gestão de Wagner estava bastante mal avaliada em Salvador. ${ }^{13}$ A estratégia de construir sua imagem como uma alternativa de mudança para Salvador parece ter cativado os eleitores. De alguma forma, ACM Neto conseguiu se apresentar como um candidato novo, que iria resgatar a autoestima do povo de Salvador, um político que seria capaz de "renovar" o carlismo através do diálogo, da defesa da diversidade e da autonomia municipal, dimensões que diferem do repertório simbólico tradicional do carlismo.

Essas duas perspectivas foram, de alguma forma, confirmadas logo após o resultado das eleições. Ao fim da apuração, seus correligionários comemoraram e carregaram o prefeito eleito no seu comitê aos gritos de: "Ô, ACM voltou... ACM voltou...”, além de muitas fotos do ex-senador. ACM Neto chorou e dedicou a vitória ao seu avô: "Agora eu sei que, onde quer que ele esteja, está tão feliz quando qualquer um de nós". No entanto, nas suas primeiras entrevistas como prefeito eleito, frisou que "A disputa acaba hoje" e que pretenderia manter uma relação "extremamente harmônica"com os governos estadual e federal. (Vou..., 2012) Sobre isso, e a relação com a oposição, afirmou ainda:

Soube que Dilma declarou que irá dar um tratamento correto as todos os prefeitos, independente de partido, e é o que a gente espera dela. Ela é presidente de todos os soteropolitanos e eu serei o prefeito de todos os soteropolitanos, então, nessa perspectiva, acabou a disputa, acabou o palanque. Quero ser parceiro do governo estadual e federal e saberei reconhecer e dar os devidos créditos para

${ }^{13}$ De acordo com o publicado no Site da Revista ISTO É de 24 de agosto de 2012, naquele mês somente 16\% dos eleitores de Salvador consideravam a gestão estadual como ótima ou boa. 
tudo que o governo federal e estadual fizerem em Salvador. [...] Vou dialogar com a oposição. Muitas pessoas vão até se assustar com isso, mas vou fazer sim. Não acredito que políticos como Waldir Pires (PT) e Edvaldo Brito (PTB) vão querer prejudicar Salvador (Vou..., 2012).

O interessante desse episódio, para além das proximidades entre a estratégia política de ACM Neto e a tradição carlista identificadas nessa campanha, é que ACM Neto foi vitorioso aos gritos de "ACM voltou", no momento em que derrotara um elemento clássico da tradição carlista, o discurso de alinhamento e da submissão do município, no caso Salvador, à elite governante estadual, que, naquela eleição, foi protagonizada pelo PT.

Em 2016, diferentemente das eleições de 2012, quando houve uma grande polarização entre PT e DEM, as eleições foram marcadas pelas críticas de todos os candidatos ${ }^{14}$ à gestão de ACM Neto, muito bem avaliada pelos soteropolitanos. ${ }^{15}$ Diante desse contexto, a postura do prefeito foi a de evitar se expor ${ }^{16}$, deixando, em primeiro plano, a propaganda de seus feitos na prefeitura.

Nessas eleições, ACM Neto contou com a maior aliança alcançada entre os candidatos: 15 partidos e 541 candidatos a vereador. Mas, sem dúvida, a principal aliança do prefeito foi com o PMDB. Nesse âmbito, é importante ڤั่ ressaltar que as eleições municipais, especial定 mente nas capitais, foram marcadas pelo contexto da crise política e pelo processo de impeachment da presidente Dilma. Nesse sentido, mesmo antes das eleições, ficou evidente, nos discursos de ACM Neto, seu posicionamento

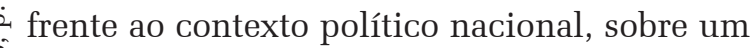
possível governo de Temer, pois ele afirmou que seria o melhor para a Bahi "O vice-presi-

$>14$ Além de ACM Neto, participaram dessas eleições os candidatos: Alice Portugal (PC do B), Sargento Isidoro (PDT), Cláudio Silva (PP), Célia Sacramento (PPL) Fábio Nogueira (PSOL) e Rogério da Luz (PRTB).

15. Segundo dados do IBOPE, a gestão de ACM Neto foi considerada boa ou ótima por $71 \%$ dos soteropolitanos. (Toledo, 2016)

${ }^{16}$ Isso fica bastante evidente com o seu não comparecimento a nenhum dos debates realizados pelas emissoras, exceto ao debate da Rede Bahia, empresa de sua família. dente conhece as pautas de Salvador, até porque foi avalista e interlocutor de acordos firmados ano passado com governo federal, acordos que não foram cumpridos" (Sotero, 2016, p. 6).

A expressão mais clara da aliança com o PMDB se efetivou com a escolha do vice-prefeito em sua chapa, Bruno Reis. Tal decisão se consolidou depois de muitas negociações com toda base aliada, e ACM Neto, nesse processo, se mostrou bastante conciliador, deixando evidente sua proximidade com Geddel Vieira Lima, principal liderança do PMDB da Bahia, e a importância de sua articulação com o provável governo de Michel Temer. Quanto à relação com o PMDB, declarou:

Já disse e vou repetir, o PMDB teria peso nessa decisão em qualquer hipótese. É o maior partido do meu conjunto de aliados. Seja para o presente ou para o futuro, é imprescindível essa parceria. O PMDB tem muita importância [...] a pressão dos aliados é 'normal'. Não era diferente do que eu podia imaginar; natural que os partidos tenham suas pretensões. Isso legitima a escolha da chapa. A escolha não é uma imposição minha, de ACM Neto, é uma construção coletiva. Eu podia começar escolhendo um vice e depois buscar aliados, mas eu fiz outro caminho: fiz o caminho de construir um vice, uma chapa fruto de um ordenamento político coletivo. Todos os critérios pesam, políticos, técnicos [...] (Biaggio, 2016, p. 8).

Agora vamos ter uma relação fluida e arejada com o governo federal. Torci muito para que o ministro Geddel tivesse posição de destaque e tenho certeza que ele terá cuidado extremo com Salvador (Silva, 2016, p. 8).

Apesar dessa relevância do PMDB na indicação do vice-prefeito, é importante ressaltar que Bruno Reis é um político fortemente ligado a ACM Neto ${ }^{17}$, tendo iniciado sua carreira como assessor parlamentar do então deputado e, posteriormente, saído candidato a deputado estadual em "dobradinha” com ele.

Ao longo dessa campanha, a maioria dos apelos de ACM Neto, entretanto, não se diri-

${ }^{17}$ Assim como Léo Prates (DEM), eleito vereador em 2012, ambos eram ex-assessores dele, não tinham liderança política própria e começaram sua carreira política à sombra de ACM Neto, que começou a formar um grupo próprio. 
giu a críticas ou alusões ao contexto político nacional, embora, não tenha deixado de citar a falta de apoio do governo estadual e federal. Sua principal estratégia, dessa forma, centrou-se na defesa de sua gestão como eficiente, tendo declarado, em entrevista ao jornal A TARDE publicada em 25 de setembro de 2016:

As pessoas, neste momento, querem saber exclusivamente da cidade. Como estava Salvador em 2012, como está Salvador hoje? No que avançou, quais são as expectativas para o futuro? [...] mesmo com as dificuldades impostas pela crise orçamentária do governo federal, que conteve verbas para obras, e com a baixa arrecadação da prefeitura, conseguimos pôr em prática muitos projetos [...] a prefeitura utilizou reservas feitas desde o início da gestão e cortou despesas. Fizemos um trabalho de contenção de despesas [...] Tem que reduzir para garantir que os serviços públicos funcionem bem e para que a prefeitura possa cumprir o compromisso assumido de entregar obras (França, 2016, p. 8).

Ficou claro, nessa campanha, que a estratégia de ACM Neto se pautou em mostrar seus feitos na gestão municipal, ${ }^{18}$ evidenciando sua capacidade administrativa como gestor, de conter despesas, procurar novas formas de conseguir recursos para a cidade mesmo frente ao fato de "estar sozinho". Apesar dessa ênfase, ao longo da campanha ACM Neto enalteceu a importância do Governo Temer e a presença do Ministro Geddel Vieira Lima, "seu aliado", como importante interlocutor no Governo Federal.

ACM Neto foi reeleito nesse ano com uma grande margem de votação $\left(74 \%{ }^{19}\right.$ dos votos válidos) - o segundo prefeito mais bem votado entre as capitais -, o que pode ser ex-

${ }^{18} \mathrm{E}$ com isso foi reeleito. Obteve cerca de $74 \%$ dos votos válidos e venceu nas 20 zonas eleitorais de Salvador com mais de $70 \%$ dos votos. (ACM..., 2016)

${ }^{19}$ Além disso, das 43 cadeiras disponíveis para o legislativo municipal a coligação de ACM Neto ocupou 29, sendo seis do DEM. Importante ressaltar também o crescimento do DEM no pleito municipal deste ano, quando saltou de 9 em 2012 para 39 prefeituras, entre os 417 municípios da Bahia, tendo vencido em alguns dos maiores municípios baianos como Feira de Santana, Barreiras, Camaçari e Alagoinhas. Além da desidratação eleitoral do PT, esse crescimento pode ser imputado à agência de ACM Neto que fez campanha para seus correligionários em outros municípios. plicado pela conjugação de grupos específicos de eleitores, entre eles uma base tradicional carlista, um eleitorado mais jovem que ACM Neto vem se esforçando para mobilizar e ainda a parcela antipetista, que estava insatisfeita com a crise política do Brasil, sobretudo no que tange à corrupção.

Em suma, ao longo das análises das campanhas de ACM Neto para deputado federal e para prefeito de Salvador, foi possível perceber que a imagem construída foi fortemente influenciada tanto pelos contextos político-eleitorais de cada ano quanto pelo tipo específico de eleição, proporcional ou majoritária, e isso, de certo modo, interferiu fortemente na vinculação aos elementos da tradição carlista.

\section{CONSIDERAÇÕES FINAIS}

Este trabalho teve como objetivo analisar em que aspectos a estratégia política de ACM Neto se vincula e (ou) se afasta da tradição do carlismo, tendo como pano de fundo a relação entre elites e instituições.

Os achados da pesquisa apontam para uma complexidade que poderia dar lugar a afirmar, que tanto houve uma proximidade mais ou menos "automática", porque genética, entre as estratégias políticas de ACM Neto e da tradição carlista, como, ao contrário, a estratégia de um novo ator se construiu a partir do - e resultando no - seu distanciamento em relação à tradição. A pesquisa mostrou, no entanto, que é preciso compreender tais possibilidades de interpretação e, ao mesmo tempo, oferecer opções alternativas a essas configurações polares através de uma análise da trajetória de ACM Neto nos diversos contextos políticos do período.

Inicialmente, é importante destacar como ACM Neto se mantém muito próximo ao repertório simbólico tradicional do carlista que sempre mobilizou a defesa da competência técnica, da moralidade do homem público e o regionalismo político. Porém ele também utilizou ideias distintas, como aquelas vincu- 
ladas à juventude, à necessidade de conciliação e diálogo.

Em termos das alianças políticas, ficou claro que, durante sua atuação parlamentar, o deputado colocou-se como oposição no nível federal, permanecendo alinhado ao mesmo campo de alianças do carlismo durante a década de 90, em especial ao PSDB, embora a condição de oposição nítida e persistente represente, em si mesma, um importante ponto de afastamento do deputado da tradição carlista, para a qual o governismo, em âmbito nacional, sempre foi, no mínimo, uma meta, na maior parte do tempo, realizada.

Desse modo, faz-se importante analisar a relação das estratégias políticas de ACM Neto com os sistemas partidários e eleitorais. O deputado iniciou sua trajetória política em 2002, quando, na Bahia, vigorava um subsistema estadual competitivo, com características bipartidárias, porém integrando uma facção da elite política que exercera até bem pouco tempo antes um domínio em situação de sistema competitivo com partido predominante (Sartori, 1982). Essa mudança do formato institucional da competição eleitoral exigia, por parte da facção da elite, a produção de estratégias adaptativas. Nesse sentido, a estratégia de ACM Neto é um exemplo emblemático, pois - ele construiu sua trajetória política em um conN texto de maior competição político-eleitoral e, mesmo estando na oposição, conseguiu êxito nesse novo cenário, principalmente através da única arena política que lhe sobrara, a atuação parlamentar na Câmara dos Deputados.

Mesmo frente a um arranjo institucional que limita as possibilidades de atuação legislativa ${ }^{20}$, como deputado de oposição, ACM Neto

हें ${ }^{20}$ No contexto do presidencialismo de coalizão brasileiro,

$>$ o legislativo tem sido descrito como arena que deixa pou-

ثิ cas oportunidades de sucesso legislativo para parlamen-

tares individuais. O Legislativo brasileiro é caracterizado

2 por uma parte relevante da literatura como uma institui-

స్ ção reativa e frágil (Santos, 2006), quando comparada ao

- poder do Executivo, que controla a agenda política através

$\mathbb{T}$ das medida).s provisórias e projetos de lei, contando com

o a disciplina partidária decorrente do arranjo institucional

(Figueiredo; Limongi, 1998 Assim, o legislativo federal

não tem a capacidade de empreender o encadeamento da

agenda legislativa, de modo que suas ações fiscalizadoras

J se tornam residuais (Anastasia; Inácio, 2010). Em geral, não teve uma atuação parlamentar meramente reativa, nem ficou esperando passivamente pela eleição seguinte para se tornar situação. No plano subnacional, ainda que isso não contradiga a literatura, sua atuação parlamentar destacada em termos da construção do seu papel de liderança política de oposição permitiu ao deputado alcançar um posto majoritário na capital do estado. Para a base estadual, portanto, esteve longe de ser insignificante o papel de sua atuação parlamentar, posto que ela lhe permitiu alcançar outros horizontes na carreira, além de assumir algum cargo no governo federal.

Esse processo demonstrou a capacidade de atuação de uma elite política estadual tradicional de alcançar alguns de seus objetivos, mesmo premida pelas instituições e regras do jogo, de um lado, e pelos contextos desfavoráveis, de outro.

Diante de tal trajetória e dos achados da pesquisa, pode-se afirmar que as estratégias adaptativas utilizadas por ACM Neto estiveram, muitas vezes, vinculadas a uma renovação da tradição carlista. Entretanto, os momentos de renovação estiveram vinculados a uma lógica mais profunda, ligada a um novo contexto político e de correlações de forças, assim como a determinadas regras do jogo que impuseram maiores dificuldades ou se apresentaram como desfavoráveis ao ator político.

Isso se expressa, por exemplo, no modo como esse ator construiu sua relação com seu partido político. Especialmente no que se refere à relação entre elites e partidos nessa arena de atuação política, fica claro, na trajetória de ACM Neto, o peso variável que, em diferentes momentos, sua estratégia confere às condições de representante e líder da facção da elite estadual ou do partido nacional que representa. No primeiro mandato, houve um maior dile-

portanto, as principais atividades legislativas acabam sendo apenas de "cooperação" com o Executivo e ficam nas mãos das coalizões da situação, de modo que ao parlamentar de oposição restam poucas alternativas de atuação. Mesmo em uma interpretação mais matizada, como a de Palermo (2000), que leva em consideração a capacidade das elites nesse processo, o cerne das negociações permanece centralizado no Executivo, especialmente através da ação do presidente. 
ma, por assim dizer, frente a essa relação, já que houve uma primazia da elite estadual, uma vez que seu grupo estava na situação no executivo do estado, enquanto que, na condição de oposição, o deputado tenha necessitado se colocar dentro da lógica dos partidos na Câmara. No segundo mandato, esse dilema diminui, e o partido passou a ter primazia nas estratégias políticas de ACM Neto, posto que ele se tornara líder, mas também muito influenciado pelo contexto de enfraquecimento da elite estadual. No último mandato, o partido ganha, mais uma vez, um lugar importante, uma vez que o deputado se utiliza da sua condição de líder para construir um forte discurso oposicionista ao governo federal e estadual, sem, contudo se desvincular da elite do estado, acumulando forças para as eleições de 2012. Em 2016, no plano municipal, ele mostrou habilidade na construção de uma ampla coligação para competir nas eleições e mostrou uma combinação da lógica partidária junto aos interesses de uma elite.

Esse processo, portanto, evidencia que as estratégias políticas de ACM Neto foram marcadas por uma sintonia no manejo do seu papel como líder de uma facção da elite estadual tradicional e como líder do partido que representava em âmbito nacional.

Dessa forma, com o estudo de suas estratégias políticas, é possível dizer que ele soube aproveitar o legado do grupo carlista, especialmente no início de sua carreira política, e, ao longo da sua trajetória, foi galgando novas frentes, sobretudo pela premência de lugar de oposição a partir de 2006, construindo, através da atuação parlamentar, sua inserção na política nacional, a qual, por sua vez, foi relevante na construção de alianças para seu fortalecimento na política estadual baiana. Esse papel se consolida em 2016, quando foi reeleito para a prefeitura de Salvador, tornando-se uma das principais lideranças da oposição ao governo do estado na Bahia.

Essa consolidação tem permitido a ACM Neto a construção de uma marca própria de agir politicamente. Um aspecto muito relevan- te nesse sentido é sua relação com o eleitorado jovem, bem como sua liderança frente a "jovens políticos”. Em termos de comportamento político, ainda que premido pelo fato de estar na oposição ao longo da maior parte de sua carreira, aprendeu a ter um perfil mais conciliador e menos personalista. Entendeu, desde o início de sua trajetória, a importância de construir alianças políticas para galgar êxito em suas metas.

Por fim, a construção dessa renovação - que resultou no fortalecimento tanto desse ator político como membro de uma elite regional quanto do seu partido nesse espaço subnacional - se configurou como mais uma estratégia adaptativa dessa elite frente aos contextos políticos desfavoráveis e às regras do jogo institucional. Os desdobramentos dessa renovação e a abrangência dos seus impactos serão testados já nas eleições de 2018, quando tudo indica que ACM Neto se candidatará, pela primeira vez, ao governo do estado da Bahia.

Recebido para publicação em 21 de março de 2017 Aceito em 20 de julho de 2017

\section{REFERÊNCIAS}

ACM Neto é reeleito prefeito de Salvador no primeiro turno. Correio, Salvador, 2 out. 2016. Disponível em: <http://www.correio24horas.com.br/noticia/nid/acmneto-e-reeleito-prefeito-de-salvador-no-primeiro-turno/> Acesso em: 2 out. 2016.

ANASTASIA, F.; CASTRO, M.; NUNES, F. Determinantes do Comportamento Particularista de Legisladores Estaduais Brasileiros. Dados, Rio de Janeiro, v. 52, n. 4, p. 961-1001, 2010.

ANASTASIA, F.; INÁCIO, M. Democracia, Poder Legislativo, Interesses e capacidades. Cadernos ASLEGIS, Brasília, DF, n. 40, p. 33-40, maio/ago. 2010.

BERNARDI, B. B. O conceito de dependência de trajetória (path dependence): definições e controvérsias teóricas. Perspectiva, São Paulo, v. 41, p.137-167, jan/jun. 2012.

BIAGGIO, T. Bruno Reis será o vice na chapa de ACM. A Tarde, Salvador, p. 8, 5 ago. 2016.

BOTTOMORE, T. As elites e a sociedade. Zahar. Rio de Janeiro, 1964

CALESTINO, S. Uma oficina para políticos. A Tarde, Salvador, p. 4, 20 abr. 2010

CHEIBUB, J. A., FIGUEIREDO, A.; LIMONGI, F. Partidos Políticos e Governadores como Determinantes do Comportamento Legislativo na Câmara dos Deputados, 
1988-2006. Dados , Rio de Janeiro, v. 52, n. 2, p. 263-299, jun. 2009 .

CODATO, A. Parâmetros para uma análise empírica da relação entre ideias, elites e instituições. Política \& Sociedade, Florianópolis, v. 7, n. 12, p. 23-48, abr. 2008.

CODATO, A. Elites e Instituições no Brasil: uma análise contextual do Estado Novo. 2008. Tese (Doutorado em Ciência Política) - Instituto de Filosofia e Ciências Humanas, Universidade Estadual de Campinas, Campinas, 2008.

DANTAS NETO, P. F. Bahia, a paz dos vencedores: liderança, partido e elite política após as eleições de 2010. In: SIMPOSIO- NORDESTE 2010: OS SENTIDOS DO VOTO, 12., 2010, Salvador. Anais... Recife: Fundação Joaquim Nabuco, 2010a.

DANTAS NETO, P. F. O carlismo para além de ACM: estratégias adaptativas de uma elite política estadual. In: SOUZA, C.; DANTAS NETO, P. F. (Org.). Governo, políticas públicas e elites políticas nos estados brasileiros. Rio de Janeiro: Revan, 2006a, p. 247-286.

DANTAS NETO, P. F. Mudança política na Bahia: circulação, competição ou pluralismo de elites? In: CORTEZ, H.; SPINELLI, J. L. (Org.). Nordeste 2006: os sentid do voto: análises interpretativas dos resultados eleitorais nas capitais do Nordeste. Natal: EDUFRN, 2010a. p. 71-97.

DANTAS NETO, P. F. Tradição, autocracia e carisma- a política de Antônio Carlos Magalhães na modernização da Bahia (1954-1974). Belo Horizonte: Ed. UFMG, 2006b.

FRANÇA. P. É possível vitória no primeiro turno. A Tarde, Salvador, p. 8, 25 set. 2016.

FIGUEIREDO, A.; LIMONGI, F. Bases Institucionais do Presidencialismo de Coalizão. Lua Nova, São Paulo, n. 44, p. 81-106, 1998.

HALL, P. A.; TAYLOR, R. As três vertentes do neoinstitucionalismo. Lua Nova, São Paulo, n. 58, p. 193-223, 2003.

KAPLAN, A.; LASSWELL, H. Poder e sociedade. Brasília, DF: EdUNB,1984.

LAVAREDA, A.; TELLES, H. (Org.). A lógica das eleições municipais. Rio de Janeiro: FGV, 2016.

LIMONGI, F. Estudos Legislativos. In: MARTINS, C. B. Aorizontes das ciências sociais no Brasil: ciência política. - São Paulo: ANPOCS, 2010. p. 28-54.

$\therefore$ MAGALHÃES NETO, A. C. A Bahia do presente sente falta de ACM. A Tarde, Salvador, 20 abr. 2010.

. MARENCO, A. Estudos de elites políticas explicam como ${ }_{2}^{\pi}$ instituições tornam-se instituições? BIB: Revista Brasileira in de Informação Bibliográfica em Ciências Sociais, Rio de เป็ Janeiro, v. 65, p. 5-26, 2008.

命 MOORE JÙNIOR, B. As origens sociais da ditadura e ฟ da democracia: senhores e camponeses na gestação do 2 mundo moderno. Lisboa: Cosmos; São Paulo. Martins $\therefore$ Fontes, 1983.

\& NUNES, E. A gramática política do Brasil: clientelismo e on insulamento burocrático. Rio de Janeiro. Zahar, 1997.

$>$ PALERMO, V. Comos e governa o Brasil? o debate sobre ثิ Instituições Políticas e Gestão de Governo. Dados, Rio de J Janeiro, p. 521-557, v. 43, n. 3, 2000
PEREIRA, C. G. Continuidade ou Mudança? análise comparativa entre os Governos de Antônio Carlos Magalhães em 1971-1975 e 1991-1995. 2007. $124 \mathrm{f}$. Dissertação (Mestrado em Ciências Sociais) -Universidade Federal da Bahia, Faculdade de Filosofia e Ciências Humanas, Salvador, 2007.

PEREIRA, C. G. Renovação como estratégia de preservação: ACM Neto e a tradição carlista. 2014. 204 f. Tese (Doutorado em Ciências Sociais) - Faculdade de Filosofia e Ciências Humanas, Universidade Federal da Bahia, Faculdade de Filosofia e Ciências Humanas, Salvador, 2014.

PERES, P. S. Comportamento ou Instituições: a evolução histórica do neo-institucionalismo da ciência política. Revista Brasileira de Ciências Sociais, São Paulo, v. 23 n. 68, p. 53-71, out. 2008.

PERISSINOTTO, R. M.; CODATO, A. N. Apresentação: por um retorno à Sociologia das elites. Revista de Sociologia e Política, Curitiba, v. 16, n. 30, p. 7-15, 2008.

PERISSINOTO, R. As elites políticas-questões de teoria e método. Curitiba: Ibpex, 2009.

REIS, F. W. (Org.). Os partidos e o regime: a lógica do processo eleitoral brasileiro. São Paulo: Símbolo, 1978.

(O) RENASCER do carlismo. A Tarde, Salvador, 11 abr. 2010 .

ROCHA, V. Rejeição de Neto avança e de João diminui. $A$ Tarde, Salvador. p. 8, 4 out. 2008a.

ROCHA, V. Os tempos são outros, diz Neto. A Tarde. Salvador, p. 6, 19 jun. 2008b.

SANTOS, F. G. M. Organización y proceso legislativo en el presidencialismo brasileño. Política, Santiago, v. 47, p. 71-97, 2006

SANTOS, F. G. M.; AMORIM NETO, O. A Produção Legislativa no Congresso. In: VIANNA, L. W. (Org.). A Democracia e os Três Poderes no Brasil. Belo Horizonte: Editora UFMG, 2002. p. 91-139.

SARTORI, G. Partidos e sistemas partidários. Rio de Janeiro: Zahar, 1982

SILVA, Y. Neto diz que Temer acelerará projetos municipais. A Tarde, Salvador, p. 8, 13 maio 2016.

SOTERO, A. Temer seria melhor para a Bahia, afirma Neto. A Tarde, Salvador, p. 6, 21 de abr. 2016.

TOLEDO, J. R. de. O ranking Ibope dos prefeitos das capitais. Estadão, São Paulo, 8 set. 2016. Disponível em: <http://politica.estadao.com.br/blogs/vox-publica/ ranking-2016-dos-prefeitos-das-capitais-ibope/>. Acesso em: 8 set. 2016.

VASCONCELOS, L. Novo Governo: Wagner começa a negociar com aliados para reformar sua equipe. A Tarde, Salvador, p. 11, 31 out. 2006

"VOU retribuir com quatro anos de muito trabalho", diz prefeito eleito ACM Neto:

democrata dedicou vitória ao avô, falecido senador Antônio Carlos Magalhães. Ibahia, Salvador, 28 out. 2012. Disponível em: < http://www.ibahia.com/detalhe/noticia/ vou-retribuir-com-quatro-anos-de-muito-trabalho-dizprefeito-eleito-acm-neto/>. Acesso em: 28 out. 2012. 


\section{THE GAME BETWEEN ELITES AND INSTITUIONS: the political strategies of ACM Neto and his carlista tradition}

\author{
Carla Galvão Pereira
}

This article aims to analyze the strategies of a political actor in the state of Bahia and in the national scenario, ACM Neto (current mayor of Salvador, Brazil) and his relation with carlista tradition. Carlismo is a term that refers to a group formed in the State of Bahia around the strong leadership of ACM Neto's grandfather, who for some decades was the most important politician in the state and one of the most influential in Brazil. Based on the theoretical background of the relationship between elites and political institutions in contemporary democracies, this article seeks to identify the political strategies of this political actor between 2002 and 2016, discussing how ACM Neto was related to the carlista group and its tradition. This article analyses the parliamentary performance and the political alliances built during ACM Neto's mandate as a federal deputy (20022012) and the symbolic repertoire mobilized in the campaigns for the proportional elections for federal deputy $(2002,2006,2010)$ and for the majoritarian elections for Mayor of Salvador, capital of the State of Bahia (2008, 2012, 2016).

Keywords: ACM Neto, Carlismo. Political Elites. Institutions.

\section{LE JEU ENTRE LES ÉLITES ET LES INSTITUTIONS: les stratégies politiques de ACM Neto et la tradition carliste}

Carla Galvão Pereira

L'objectif de cet article est d'analyser, dans le cadre de l'état de Bahia et au niveau national, les stratégies d'un acteur politique, ACM Neto (actuel maire de Salvador) et ses relations avec la tradition carliste, un groupe formé dans l'État de Bahia autour de l'énorme leadership de son grand-père ACM qui, pendant plusieurs décennies, a été le politicien le plus important de l'État de Bahia et l'un des plus influents au Brésil. Basé sur la théorie de la relation entre les élites et les institutions politiques dans les démocraties contemporaines, l'étude cherche à identifier les stratégies politiques de cet acteur politique entre 2002 et 2016, à savoir comment ACM Neto a été lié au groupe carliste et à sa tradition. Pour ce faire, on analyse la performance parlementaire et les alliances politiques élaborées dans le cadre de son mandat en tant que député fédéral (2002-2012) ainsi que le répertoire symbolique mobilisé dans les campagnes proportionnelles pour l'élection à député fédéral $(2002,2006,2010)$ et les campagnes majoritaires pour l'élection à maire de Salvador (2008, 2012, 2016).

Mots-CLÉs: ACM Neto. Carlisme. Élites Politiques. Institutions.

Carla Galvão Pereira - Doutora em Ciências Sociais pela UFBA. Professora do Departamento de Ciência Política Universidade Federal da Bahia. Integra o Núcleo de Pesquisa Instituições Políticas Subnacionias/ CRH/UFBA, desenvolvendo pesquisas na área de Elites e Instituições. Publicação recente: Renovação como estratégia de preservação: ACM Neto e a tradição carlista. 2014. $204 \mathrm{f}$. Tese (Doutorado em Ciências Sociais) - Faculdade de Filosofia e Ciências Humanas, Universidade Federal da Bahia, Salvador, 2014. 
